\title{
Characterization of Epstein-Barr virus (EBV)- infected cells in EBV-associated hemophagocytic lymphohistiocytosis in two patients with X-linked lymphoproliferative syndrome type 1 and type 2
}

\author{
Xi Yang ${ }^{1,2}$, Taizo Wada ${ }^{3}$, Ken-Ichi Imadome ${ }^{4}$, Naonori Nishida', Takeo Mukai ${ }^{5}$, Mitsuhiro Fujiwara \\ Haruka Kawashima ${ }^{6}$, Fumiyo Kato ${ }^{6}$, Shigeyoshi Fujiwara ${ }^{3}$, Akihiro Yachie ${ }^{3}$, Xiaodong Zhao ${ }^{2}$, Toshio Miyawaki ${ }^{1}$ and \\ Hirokazu Kanegane ${ }^{1 *}$
}

\begin{abstract}
Background: $X$-linked lymphoproliferative syndrome $(X L P)$ is a rare inherited immunodeficiency by an extreme vulnerability to Epstein-Barr virus (EBV) infection, frequently resulting in hemophagocytic lymphohistiocytosis (HLH). XLP are now divided into type 1 (XLP-1) and type 2 (XLP-2), which are caused by mutations of SH2D1A/SLAMassociated protein (SAP) and X-linked inhibitor of apoptosis protein (XIAP) genes, respectively. The diagnosis of XLP in individuals with EBV-associated HLH (EBV-HLH) is generally difficult because they show basically similar symptoms to sporadic EBV-HLH. Although EBV-infected cells in sporadic EBV-HLH are known to be mainly in $\mathrm{CD}^{+} \mathrm{T}$ cells, the cell-type of EBV-infected cells in EBV-HLH seen in XLP patients remains undetermined.
\end{abstract}

Methods: EBV-infected cells in two patients (XLP-1 and XLP-2) presenting EBV-HLH were evaluated by in EBER-1 in situ hybridization or quantitative PCR methods.

Results: Both XLP patients showed that the dominant population of EBV-infected cells was CD $19^{+}$B cells, whereas EBV-infected $\mathrm{CD}^{+} \mathrm{T}$ cells were very few.

Conclusions: In XLP-related EBV-HLH, EBV-infected cells appear to be predominantly B cells. B cell directed therapy such as rituximab may be a valuable option in the treatment of EBV-HLH in XLP patients.

Keywords: B cells, Epstein Barr virus, Hemophagocytic lymphohistiocytosis, X-linked lymphoproliferative syndrome

\section{Introduction}

Hemophagocytic lymphohistiocytosis (HLH) is clinically characterized by prolonged fever, hepatosplenomegaly, hypertriglyceridemia, systemic hypercytokinemia and cytopenia [1]. HLH consists of primary (familial) and secondary (infection, lymphoma or autoimmune diseaseassociated) types. Approximately half of all infectionassociated HLH cases involves the Epstein-Barr virus (EBV) [2]. Most cases of EBV-HLH are sporadic, but a few cases may present the first presentation of X-linked lymphoproliferative syndrome (XLP) [3]. XLP is a rare,

\footnotetext{
* Correspondence: kanegane@med.u-toyama.ac.jp

'Department of Pediatrics, Graduate School of Medicine and Pharmaceutical

Science, University of Toyama, Toyama, Japan

Full list of author information is available at the end of the article
}

inherited immunodeficiency that is characterized by an extreme vulnerability to EBV infection and shows variable clinical phenotypes, including severe or fatal EBVHLH (60\%), malignant B-cell lymphoma (30\%), and progressive dysgammaglobulinemia (30\%) [3]. The first genes that is responsible for XLP was identified as the SH2D1A/SLAM-associated protein (SAP) gene in 1998 [4-6], and mutations in the X-linked inhibitor of apoptosis protein $(X I A P)$ gene can also lead to the clinical phenotype of XLP in 2006 [7]. XLP is now considered to comprise two distinct diseases, namely XLP-1 (SAP deficiency) and XLP-2 (XIAP deficiency).

In addition to $B$ cells, EBV can infect other cell types, including epithelial cells, $\mathrm{T}$ cells and natural killer (NK) cells [8]. Studies have shown that activated $\mathrm{T}$ cells, 
particularly $\mathrm{CD}^{+} \mathrm{T}$ cells, are the primary cellular target of EBV infection in sporadic EBV-HLH $[9,10]$, which reflects the pathogenic role of EBV-infected $\mathrm{CD} 8^{+} \mathrm{T}$ cells in sporadic EBV-HLH. Patients with sporadic EBVHLH are usually treated with immunochemotherapy, including dexamethasone, cyclosporine A and etoposide, and this therapy can be curable [11]. In contrast, XLPrelated EBV-HLH is usually refractory to immunochemotherapy [3]. It is possible that the poor response of XLP-related EBV-HLH to immunochemotherapy can be attributed to the type of EBV-infected cells in this disease, which may differ from the cell type that infected in sporadic EBV-HLH. We investigated the affected cell type in EBV infection of two XLP (XLP-1 and XLP-2) patients with EBV-HLH. Our results demonstrate that the predominant EBV target cells in XLP-related EBV$\mathrm{HLH}$ are $\mathrm{CD} 19^{+} \mathrm{B}$ cells, which appears to be distinct from sporadic EBV-HLH cases.

\section{Patients, materials and methods Patients}

Three patients presented with clinical features of HLH, including persistent fever, hepatosplenomegaly, cytopenia, abnormal liver function, hyperferritinemia and elevated levels of soluble interleukin-2-receptor (Table 1). The clinical features of the patients fulfilled the diagnostic criteria for HLH [1], although hemophagocytosis in

Table 1 Clinical and laboratory finding of the patients in this study

\begin{tabular}{llll}
\hline & Patient $\mathbf{1}$ & Patient $\mathbf{2}$ & Patient 3 \\
\hline Family history available & No & Yes & No \\
\hline Age at the time of the study & 4 years & 21 months & 16 months \\
\hline Age at onset & 3 years & 17 months & 16 month \\
\hline Fever & Yes & Yes & Yes \\
\hline Hepatomegaly & $4 \mathrm{~cm}$ & $5 \mathrm{~cm}$ & $2.5 \mathrm{~cm}$ \\
\hline Splenomegaly & $2 \mathrm{~cm}$ & $3 \mathrm{~cm}$ & $1 \mathrm{~cm}$ \\
\hline White blood cells $\left(\times 10^{9} / \mathrm{L}\right)$ & 11.6 & 6.36 & 3.03 \\
\hline Neutrophils $\left(\times 10^{9} / \mathrm{L}\right)$ & 1.61 & 3.915 & 0.56 \\
\hline Hemoglobin $(\mathrm{g} / \mathrm{dL})$ & 8.1 & 9.6 & 7.5 \\
\hline Platelets $\left(\times 10^{9} / \mathrm{L}\right)$ & 95 & 56 & 30 \\
\hline LDH $(\mathrm{IU} / \mathrm{L})$ & 449 & 1,693 & 1,698 \\
\hline AST $(\mathrm{IU} / \mathrm{L})$ & 88 & 122 & 453 \\
\hline ALT $(\mathrm{IU} / \mathrm{L})$ & 31 & 25 & 255 \\
\hline Ferritin $(\mu \mathrm{gg} / \mathrm{L})$ & 1,276 & 26,282 & 11,129 \\
\hline slL-2R $(\mathrm{U} / \mathrm{mL})$ & 3,162 & 2,880 & 14,334 \\
\hline IgG $(\mathrm{mg} / \mathrm{dL})$ & 1,821 & 806 & 423 \\
\hline IgA (mg/dL) & 302 & 124 & 32 \\
\hline IgM (mg/dL) & 1,843 & 40 & 18 \\
\hline Whole blood EBV-DNA (copies/mL) & 140,000 & 5,700 & $1,400,000$ \\
\hline LDH, lactate dehydrogenase; AST, aspartate amino transferase; ALT, alanine \\
amino transferase, slL-2R, soluble interleukin-2 receptor; NA: not available.
\end{tabular}

the bone marrow was not observed in patients 1 and 2 . Patient 3 was previously reported as patient HLH3 [10]. The number of EBV-DNA copies in the peripheral blood was increased from the normal level of $\leq 1 \times 10^{2}$ copies $/ \mathrm{ml}$ to $1.4 \times 10^{5}, 5.7 \times 10^{3}$ and $1.4 \times 10^{6}$ copies $/ \mathrm{ml}$ in patients 1, 2 and 3, respectively. Blood samples from the patients were obtained using standard ethical procedures with the approval of the Ethics Committee of the University of Toyama, and an analysis of the SH2D1A and XIAP genes was performed. Patient 1 showed a one-nucleotide insertion (239_240insA) in the SH2D1A gene that resulted in a frameshift and a premature stop codon (80KfsX22). Patient 2 carried a two-nucleotides deletion (1021_1022delAA) in the XIAP gene that resulted in a frameshift and a premature stop codon (N341YfsX7). Patient 3 had no mutations in the SH2D1A or XIAP gene.

\section{Cell preparation}

Peripheral blood mononuclear cells (PBMCs) were isolated from the the patients using Ficoll-Hypaque gradient centrifugation. Lymphocytes were prepared from the PBMCs by depleting the monocytes using anti-CD14 monoclonal antibody (mAb)-coated magnetic beads (Becton Dickinson, San Diego, CA) [10]. The CD19 $9^{+}$ cells, CD $56^{+} \mathrm{NK}$ cells, CD4 ${ }^{+} \mathrm{T}$ cells and $\mathrm{CD} 8^{+} \mathrm{T}$ cells were purified by positive selection from the lymphocytes using the respective mAb-coated magnetic beads. The purity of each isolated cell population was assessed by flow cytometriy analysis, and each sorted population was found to be higher than $85 \%$ pure.

\section{In situ hybridization of EBVRNA}

The presence of EBV was estimated by measuring the EBV-encoded small RNA 1 (EBER-1) mRNA using the in situ hybridization (ISH) method as described previously [10]. The sorted cells were cytocentrifuged onto silanized slides (Dako, Kyoto, Japan), and the presence of EBER-1 mRNA was determined by ISH using the alkaline phosphatase-conjugated EBER-1 antisense probe (5'-AGCAGAGTCTGGGAAGACAACCACAGACACCGTCCTCACC-3') or a sense probe.

\section{Quantitative PCR for EBV DNA}

Quantitative PCR was performed using AmpliTaq Gold and a real-time PCR 7300 system (Applied Biosystems, Foster City, CA) as described previously [12]. The PCR primers for detecting EBV DNA were selected from within the BALF5 gene, which encodes the viral DNA polymerase. The primers for amplifying the BALF5 gene sequences were as follows: forward, CGGAAGCCC TCTGGACTTC, and reverse, CCCTGTT TATCCGATGGAATG. The TaqMan probe was FAM-TATACACGCACGAGAAATGCGCC-BFQ. The PCR 
conditions were as follows: denaturation at $95^{\circ} \mathrm{C}$ for 2 minutes, annealing at $58^{\circ} \mathrm{C}$ for 15 seconds, and extension at $72^{\circ} \mathrm{C}$ for 15 seconds, and the products were subjected to 45 cycles of PCR amplification. The EBV DNA copy number was considered to be significant when more than 500 copies/ $\mu$ g of DNA were observed.

\section{Flow cytometry analysis for the $\mathrm{T}$ cell receptor $\mathrm{V} \beta$ repertoire}

Flow cytometry analysis of the T cell receptor (TCR) V $\beta$ repertoire was performed as described previously [10]. In briefl, the PBMCs were incubated with the appropriate phycoerythrin-conjugated mAbs with specificity for TCR V $\beta$ 1-23 (Immunotech, Marseille, France), fluorescein isothiocyanate-conjugated anti-CD8 (Becton Dickinson) and R-PE-Cy5-conjugated anti-CD4 (Dako) mAbs. The stained cells were analyzed using a flow cytometer. TCR V $\beta$ expression is represented as the percentage of $\mathrm{CD}_{4}^{+}$or $\mathrm{CD}^{+}$cells for each receptor family.

\section{Results}

To determine the localization of EBV infection in the lymphocyte subpopulations of patient $1, \mathrm{CD} 4^{+} \mathrm{T}$ cells, $\mathrm{CD}^{+} \mathrm{T}$ cells, CD $19^{+} \mathrm{B}$ cells and $\mathrm{CD} 56^{+} \mathrm{NK}$ cells were sorted using the immunomagnetic bead method and the presence of EBV was evaluated in each lymphocyte subpopulation by EBER-1 ISH (Figure 1A). EBER-1-positive cells were observed in $34.0 \%$ of the $\mathrm{CD} 19^{+} \mathrm{B}$ cells, whereas the remaining lymphocyte subpopulations contained fewer than 0.1\% EBER-1-positive cells. Therefore, the EBV-infected cells in patient 1 were almost exclusively $\mathrm{CD} 19^{+} \mathrm{B}$ cells. In patient 3 , EBER-1-positive cells constituted $75.5 \%$ of $\mathrm{CD}^{+} \mathrm{T}$ cells, however, they were not detected among $\mathrm{CD}^{+}{ }^{+} \mathrm{T}$ cells and observed in a few of $\mathrm{CD} 19^{+} \mathrm{B}$ cells and CD $56^{+} \mathrm{NK}$ cells $(2.8 \%$ and $17.4 \%$, respectively) (Figure $1 \mathrm{~B}$ ).

The viral loads in the $\mathrm{CD}^{+} \mathrm{T}$ cells, $\mathrm{CD} 8^{+} \mathrm{T}$ cells, CD $19^{+} \mathrm{B}$ cells and $\mathrm{CD} 56^{+} \mathrm{NK}$ cells in patient 2 were determined by quantitative PCR. The number of EBV DNA genome copies in the $\mathrm{CD}_{19^{+}} \mathrm{B}$ cells was $1.8 \times 10^{4}$ copies $/ \mu \mathrm{g}$, and the copy number in the $\mathrm{CD}^{+} \mathrm{T}$ cells was $1.0 \times 10^{3}$ copies $/ \mu$ g. The EBV DNA genome could not be detected in either the $\mathrm{CD}^{+}{ }^{+} \mathrm{T}$ cells or the $\mathrm{CD}_{56}{ }^{+}$ NK cells that were isolated from patient 2 .

Flow cytometry analysis of the TCR V $\beta$ repertoire revealed a polyclonal pattern in patients 1 and 2 (Figure 2 ), which was in contrast to the skewed pattern that is most commonly seen in the $\mathrm{CD}^{+} \mathrm{T}$ cells of patients with sporadic EBV-HLH [10]. No clonal dominance in $\mathrm{CD}^{+} \mathrm{T}$ cells was demonstrated by $\mathrm{mAb}$ in patient 3 , but TCR V $\beta 13.3$ was predominantly found in the $C D 8^{+}$ $\mathrm{T}$ cells by complentarity-determining region 3 spectratyping [10].

\section{Discussion}

XLP is a severe and rare immunodeficiency disease that is characterized by an extreme vulnerability to EBV infection and frequently results in HLH [3]. XLP was first described as X-linked progressive combined immunodeficiency in 1975 by Purtilo et al. [13]. To better understand and reflect the pathophysiology of this disease, the term "X-linked lymphoproliferative disease or syndrome" has now been used. The first gene to be linked to XLP in 1998 was SH2D1A which is located on $\mathrm{Xq} 25$ and encodes the SAP [4-6]. Importantly, in 2006, a mutation in the gene that encodes the XIAP was identified as a second XLP-linked gene [7]. Thus, XLP can be divided into XLP-1 (SAP deficiency) and XLP-2 (XIAP deficiency). Most XLP patients present with EBV-HLH. Pachlopnik Schmid et al. [14] reported that the incidence of HLH in XLP-1 and XLP-2 is 55 and $76 \%$, respectively. Currently, hematopoietic stem cell transplantation (HSCT) is the only curative therapy for XLP. Therefore, an early definitive diagnosis and immediate treatment are extremely important for both life-saving intervention and an improved prognosis for XLP patients.

EBV infects the majority of the adult population worldwide and persists in B cells throughout the lifetime of normal individuals, usually without causing disease. EBV is the most common trigger for both the XLP-1 and XLP-2 phenotypes. Prior to being exposed to EBV, most patients with XLP can tolerate infections by other agents, although in vitro studies have demonstrated defects of $\mathrm{T}$ cell-mediated and humoral immunity. During an acute EBV infection, XLP patients develop normal or high levels of anti-viral capsid antigen IgM antibodies but usually lack heterophile antibodies. Initially, these patients fail to develop EBV-specific cytotoxic $\mathrm{T}$ cells, and this results in a massive and overwhelming polyclonal B cell proliferation involving lymphoid and other tissues [8]. SAP binds 2B4, which is a surface molecule involved in activation of NK cell-mediated cytotoxity. Therefore, SAP-deficient patient shows that NK cell function is impaired, allowing B cell proliferation [15]. SAP has proapoptotic function, and contributes to the maintenance of $\mathrm{T}$ cell homeostasis and to the elimination of potentially dangerous DNA-damaged cells. Thus, the loss of this function could be responsible for the uncontrol $\mathrm{T}$ cell proliferation in acute EBV infection [16].

$B$ cells are the usual cellular targets of EBV in a primary EBV infection such as infectious mononucleosis and in the sero-positive normal host [8]. After the interaction of the viral surface glycoproteins with the CD21 receptor, EBV entry into $B$ cells is mediated by HLA class II and other co-receptors. However, in cases of 


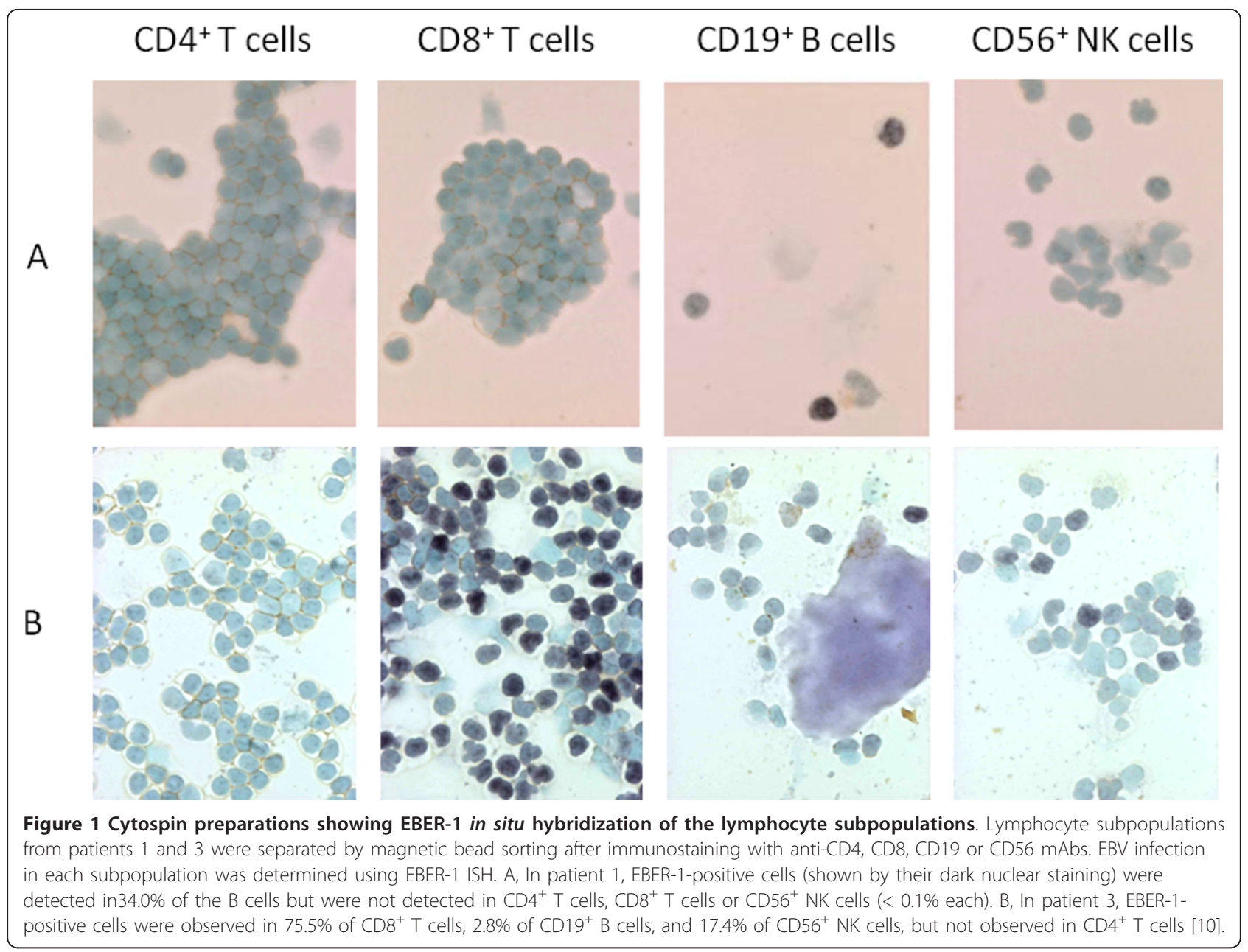

sporadic EBV-HLH, EBV infects primarily $\mathrm{T}$ cells and NK cells $[9,10,17]$. The mechanism of $\mathrm{T}$ cell infection by EBV in HLH is still unclear, but one hypothesis is that, in specific situations, $\mathrm{CD} 8^{+} \mathrm{T}$ cells express CD21, which can mediate EBV infection. Although T cells do not express the glycoprotein, they contain mRNA for CD21 [18]. In sporadic EBV-HLH cases, EBV infection into $\mathrm{B}$ cells is delayed but occurs during every case of cured EBV-HLH [17]. To the best of our knowledge, this is the first report of EBV infection status in two different types of XLP patients with EBV-HLH. The present study shows that the primary EBV-infected cells in XLP-related EBV-HLH are CD $19^{+} \mathrm{B}$ cells and not T cells or NK cells, which are a primary target of EBV infection in sporadic EBV-HLH.

For decades, clinicians and investigators have been puzzled by the differential diagnosis between XLP and sporadic EBV-HLH when they encountered a young boy presenting with EBV- HLH. We believe the different EBV target cells can provide additional information to help discriminate between XLP and sporadic EBVHLH. An evaluation of specific cell type that is infected by EBV should be considered when target therapy is applied. Most patients with sporadic EBVHLH can achieve remission by immunochemotherapy; however, patients with XLP are usually refractory to this therapy. Recently, B cell-directed therapy using an anti-CD20 mAb (rituximab) was performed in patients with XLP-1 [19]. Two XLP patients who presented with acute EBV infection were successfully treated with rituximab and were free from EBV-HLH and lymphoma for a prolonged period. In addition, rituximab combined with methylprednisolone and intravenous immunoglobulin were administered to an XLP-1 patient with EBV-HLH, and the patient achieved a remission [20]. Patient 1 was also associated with EBVassociated encephalitis and lymphoproliferative disorder. The patient's lymphoproliferative disorder was treated with rituximab, but he died of the disease. Patient 2 was successfully treated with dexamethasone 


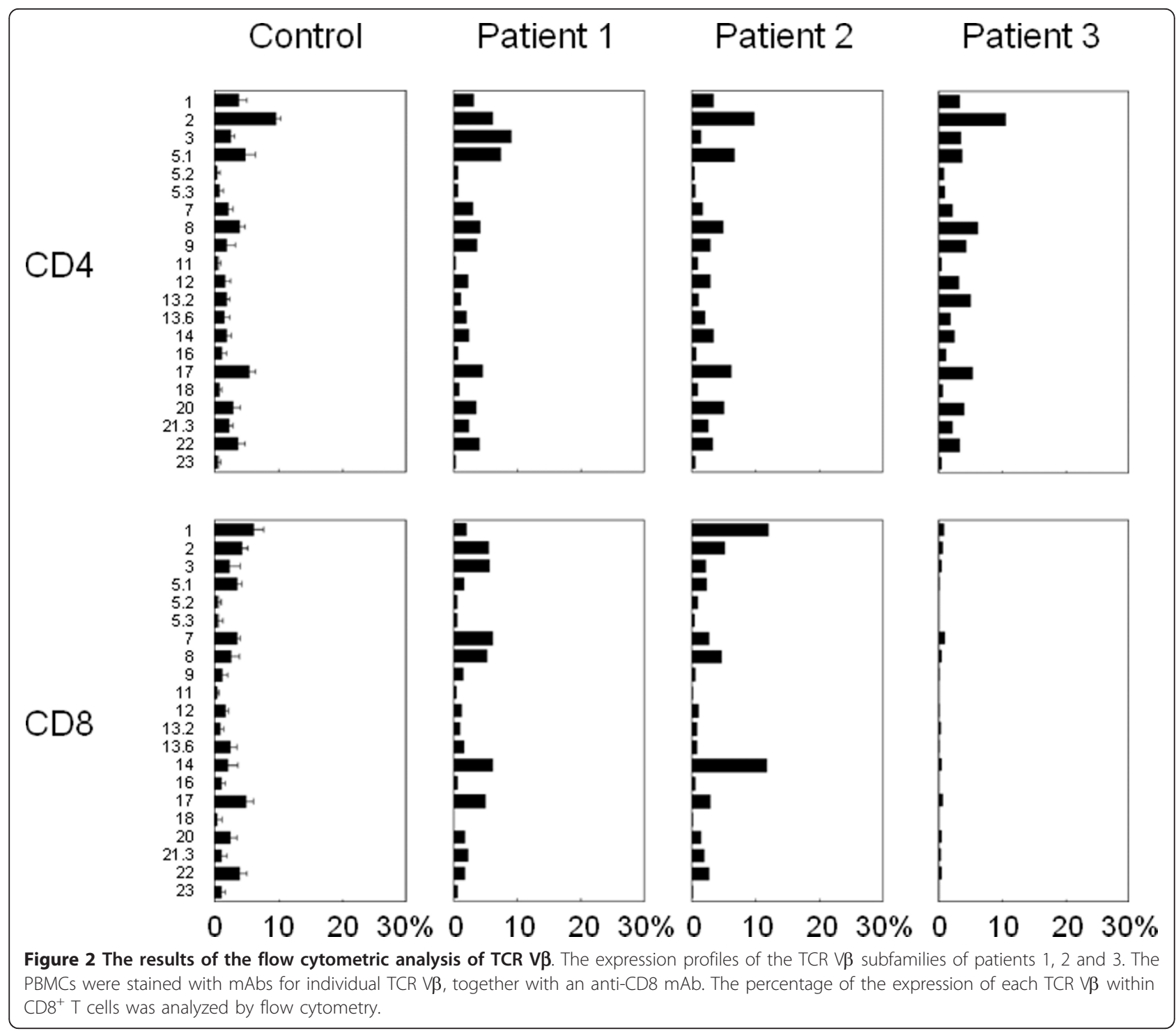

and immunoglobulin. Our data suggest that B cell target therapy can be a viable therapeutic option for an initial stage of EBV-HLH in both XLP-1and XLP-2 patients.

\section{Abbreviations}

EBER: EBV-encoded small RNA; EBV: Epstein-Barr virus; HLH: Hemophagocytic lymphohistiocytosis; HSCT: Hematopoietic stem cell transplantation; ISH: In situ Hybridization; mAb: Monoclonal antibody; NK: Natural killer; PBMC: Peripheral blood mononuclear cells; SAP: SLAM-associated protein; TCR: T cell receptor; XIAP: X-linked inhibitor of apoptosis; XLP: X-linked lymphoproliferative syndrome.

\section{Acknowledgements}

The authors would like to thank Ms. Chikako Sakai and Mr. Hitoshi Moriuch for their excellent technical assistances. This study was supported by a grant-in-aid for scientific research from the Ministry of Education, Culture, Sports, Science and Technology, Japan (TM, HK), and a grant from the Ministry of Health, Labour, and Welfare, Japan (TM).

\section{Author details}

'Department of Pediatrics, Graduate School of Medicine and Pharmaceutical Science, University of Toyama, Toyama, Japan. ${ }^{2}$ Division of Immunology, Children's Hospital of Chongqing Medical University, Chongqing, China. ${ }^{3}$ Department of Pediatrics, School of Medicine, Institute of Medical,

Pharmaceutical and Health Sciences, Kanazawa University, Kanazawa, Japan. ${ }^{4}$ Department of Infectious Diseases, National Research Institute for Child Health and Development, Tokyo, Japan. ${ }^{5}$ Department of Pediatrics, Kurashiki Central Hospital, Kurashiki, Japan. ${ }^{6}$ Department of Pediatrics, Tokyo Women's Medical University Medical Center East, Tokyo, Japan.

\section{Authors' contributions}

$X Y$ and HK wrote the manuscript. XY, TW, KI and NN performed the experimental studies. TM, MF, HK and FK managed the patients' care. SF, AY, XDZ and TM revised the manuscript. XY, TW and KI contributed equally to this study. All the authors read and approved the final manuscript.

\section{Competing interests}

The authors declare that they have no competing interests.

Received: 1 December 2011 Accepted: 10 February 2012 Published: 10 February 2012 


\section{References}

1. Henter Jl, Horne A, Aricó M, Egeler RM, Fillipovich AH, Imashuku S, Ladisch S, McClain K, Webb D, Winiarski J, et al: HLH-2004: Diagnostic and therapeutic guideline for hemophagocytic lymphohistiocytosis. Pediatr Blood Cancer 2007, 48:124-131.

2. Ishii E, Ohga S, Imashuku S, Yasukawa M, Tsuda H, Miura I, Yamamoto K, Horiuchi H, Takada K, Ohshima K, et al: Nationwide survey of hemaphagocytic lymphohistiocytosis in Japan. Int J Hematol 2007 86:58-65.

3. Seemayer TA, Gross TG, Egeler RM, Pirruccello SJ, Davis JR, Kelly CM, Okano M, Lanyi A, Sumegi J: X-linked lymphoproliferative disease: twenty- five years after the discovery. Pediatr Res 1995, 38:471-478.

4. Coffey AJ, Brooksbank RA, Brandau O, Oohashi T, Howell GR, Bye JM, Cahn AP, Durham J, Heath P, Wray P, et al: Host response to EBV infection in X-linked lymphoproliferative disease results from mutations in an SH2-domain encoding gene. Nat Genet 1998, 20:129-135.

5. Sayos J, Wu C, Morra M, Wang N, Zhang X, Allen D, Van-Schaik S, Notarangelo L, Geha R, Roncarolo MG, et al: The X-linked lymphoproliferative-disease gene product SAP regulates signals induced through the co-receptor SLAM. Nature 1998, 395:462-469.

6. Nichols KE, Harkin DP, Levitz S, Krainer M, Kolquist KA, Genovese C, Bernard A, Ferguson M, Zuo L, Snyder E, et al: Inactivating mutations in an $\mathrm{SH} 2$ domain-encoding gene in X-linked lymphoproliferative syndrome. Proc Natl Acad Sci USA 1998, 95:13765-13770.

7. Rigaud $\mathrm{S}$, Fondanèche $\mathrm{MC}$, Lambert $\mathrm{N}$, Pasquier $\mathrm{B}$, Mateo $\mathrm{V}$, Soulas $\mathrm{P}$, Galicier L, Le-Deist F, Rieux-Laucat F, Revy P, et al: XIAP deficiency in humans causes an X-linked lymphoproliferative syndrome. Nature 2006, 444:110-114

8. Tosato G, Taga K, Angiolillo AL, Sgadari C: Epstein-Barr virus as an agent of haematological disease. Baillière Clin Haematol 1995, 8:165-199.

9. Kawaguchi H, Miyashita T, Herbst H, Niedobitek G, Asada M, Tsuchida M, Hanada R, Kinoshita A, Sakurai M, Kobayashi N, et al: Epstein-Barr virusinfected T lymphocytes in Epstein-Barr virus-associated hemophagocytic syndrome. J Clin Invest 1993, 92:1444-1450.

10. Toga A, Wada T, Sakakibara Y, Mase S, Araki R, Tone T, Toma T, Kurokawa T, Yanagisawa R, Tamura K, et al: Clinical significance of cloned expansion and CD5 down-regulation in Epstein-Barr Virus (EBV)-infected CD8+ T lymphocytes in EBV-associated hemophagocytic lymphohistiocytosis. $J$ Infect Dis 2010, 201:1923-1932.

11. Imashuku S, Hibi S, Ohara T, Iwai A, Sako M, Kato M, Arakawa H, Sotomatsu M, Kataoka S, Asami K, et al: Effective control of Epstein-Barr virus-related hemophagocytic lymphohistiocytosis with immunochemotherapy. Blood 1999, 93:1869-1874.

12. Kimura H, Hoshino $Y$, Kanegane H, Tsuge I, Okamura T, Kawa K, Morishima T: Clinical and virologic characteristics of chronic active Epstein-Barr virus infection. Blood 2001, 98:280-286.

13. Purtilo DT, Cassel CK, Yang JP, Harper R: X-linked recessive progressive combined variable immunodeficiency (Duncan's disease). Lancet 1975, 1:935-940.

14. Pachlopnik Schmid J, Canioni D, Moshous D, Moshous D, Touzot F, Mahlaoui N, Hauck F, Kanegane H, Lopez-Granados E, Mejstrikova E, et al: Clinical similarities and differences of patients with X-linked lymphoproliferative syndrome type 1 (XLP-1/SAP deficiency) versus type 2 (XLP-2/XIAP deficiency). Blood 2011, 117:1522-1529.

15. Parolini S, Bottino C, Falco M, Augugliaro R, Giliani S, Franceschini R, Ochs HD, Wolf $\mathrm{H}$, Bonnefoy JY, Biassoni $\mathrm{R}$, et al: X-linked lymphoproliferative disease: 2B4 molecules displaying inhibitory rather than activating function are responsible for the inhibit of natural killer cells to kill Epstein-Barr virus-infected cells. J Exp Med 2000, 192:337-346.

16. Nagy N, Matskova L, Kis LL, Hellmah U, Klein G, Klein E: The proapoptotic function of SAP provides a clue to the clinical picture of X-linked lymphoproliferative disease. Proc Natl Acad Sci USA 2009, 106:11966-11971.

17. Kasahara $Y$, Yachie A: Cell type specific infection of Epstein-Barr virus (EBV) in EBV-associated hemophagocytic lymphohistiocytosis and chronic active EBV infection. Crit Rev Oncol Hematol 2002, 44:283-294.

18. Braun $M$, Melchers I, Peter HH, Illges $H$ : Human $B$ and $T$ lymphocytes have similar amounts of CD21 mRNA, but differ in surface expression of the CD21 glycoprotein. Int Immunol 1998, 10:1197-1202.

19. Milone MC, Tsai DE, Hodinka RL, Silverman LB, Malbran A, Wasik MA Nichols KE: Treatment of primary Epstein-Barr virus infection in patients with X-linked lymphoproliferative disease using B-cell-directed therapy. Blood 2005, 105:994-996.

20. Bond J, Shahdadpuri R, Mc Mahon C, O'Marcaigh A, Cotter M, Smith O: Successful treatment to acute Epstein-Barr virus infection associated with X-linked lymphoproliferative disorder with rituximab. Pediatr Blood Cancer 2007, 49:761-762.

doi:10.1186/2042-4280-3-1

Cite this article as: Yang et al:: Characterization of Epstein-Barr virus (EBV)-infected cells in EBV-associated hemophagocytic lymphohistiocytosis in two patients with X-linked lymphoproliferative syndrome type 1 and type 2. Herpesviridae 2012 3:1.

\section{Submit your next manuscript to BioMed Central and take full advantage of:}

- Convenient online submission

- Thorough peer review

- No space constraints or color figure charges

- Immediate publication on acceptance

- Inclusion in PubMed, CAS, Scopus and Google Scholar

- Research which is freely available for redistribution

Submit your manuscript at www.biomedcentral.com/submit
Ciomed Central 